\title{
Child Representation in Alberta: ROLE AND RESPONSIBILITIES OF COUNSEL FOR THE ChILd IN FaMILY PROCEEDINGS
}

\author{
NICHOLAS BALA
}

There has been an increase in the number of fomily law cases in Alberla where counsel is appointed to represent a child, but there is a lack of guidance and there is controversy about the role and responsibilities of counsel for the child. In other jurisdictions governmen agencies, the courts, the legislature or the law society have provided clear direction. though raking differem approaches to resolving the controversies about counsel for the child. This article reviews the different roles adopted by counsel appointed to represen a child in a family procecding: the child advocate. the best interests guardian amd the friend of the court. It is argued that in Alberta there is no single role that is appropriate for all cases. While the child's wishes should always be placed before the court, counsel should only advocate based on those wisher if the child has capacity to instruct conusel. This article offers detailed suggestions for the professional responsibilities of counsel for the child. and concludes by making recommendations for acsion by the Law Society of Alberla and Government of the Province if these bodics are to meet their responsibilitics to children.
Le nombre de causes relevant du droil de la famille oi un arocal est nomme pour representer un colfam esf $\dot{a}$ la hausse 'Il Alberfa. mais il y' a un manquic de direction et il existe une controverse a l'egard du role et des responsabilités de linvocat de l'enfam. Daws d'autras ressorts, les organismes gouvernementanx, les tribunaux, la legislature ou le barreau ont donné une direction claire, bien qu ils aient pris des dimarches differentes pour régler la controverse au sujet de l'anocat de f'enfant. Cet article revoil les differents rôles adoptes par l'awocal mommé pour represenuer l'enfant dans des pourswites relevant du stroil de la famille : Ia difense de lienfant, to turetur clans lo meilleur interet el f'ami de la cour. Il semble qu'en Alberta, il n'existe pas de role qui convieme a loules les conses. Alors que les desirs de l'enfant devraicht toujours primer pour la cour. l'avocat ne doir baser sa defense sur ces désirs que si f'enfant est en mesure de ten instruire. Cet article propose des suggestions détaillies relatives aux responsabilites professionmelles de lanocul de l'enfan el conclut par des recommandations de mesures par la Law Sociedy of Aburta at le gowvernemen de la prewince pour permetre a ces organismes d'assmmer lents responsabilite's à l'égard des enfants.

\section{TABLE OF CONTENTS}

\section{INTRODUCTION: CONTROVERSY OVER THE}

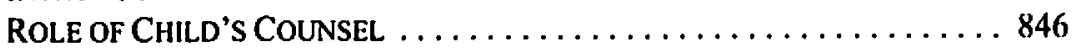

II. ROLES FOR COUNSEL: FRIEND OF THE COURT, GUARDIAN

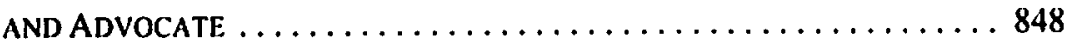

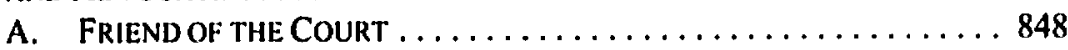

B. Best InTERESTS GuARDian $\ldots \ldots \ldots \ldots \ldots \ldots \ldots \ldots . \ldots 849$

C. Child's Advocate $\ldots \ldots \ldots \ldots \ldots \ldots \ldots \ldots \ldots \ldots . \ldots \ldots 60 \ldots$

III. THE ROLE OF COUNSEL FOR THE CHILD

- THE LEGAL CONTEXT ...................... 852

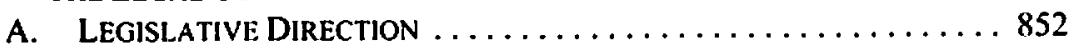

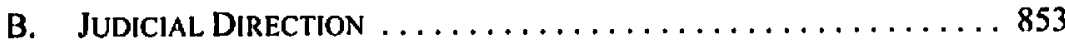

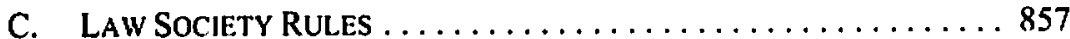

- Professor, Faculty of Law, Queen's University. This is a revised version ol' a paper presented at legal training programs on Child Representation, infra note 63 . The author wishes to acknowledge the editorial and research assistance of Joanna Harris (Queen's Law 2005), and support from the Social Sciences \& Humanities Research Council for the preparation of this paper. 
D. Government Policy $\ldots \ldots \ldots \ldots \ldots \ldots \ldots \ldots \ldots \ldots \ldots . \ldots \ldots 8$

IV. CAPACITY to InStRuct Counsel .................. 859

V. ASSESSING CAPACITY AND DETERMINING ROLE $\ldots \ldots \ldots \ldots \ldots \ldots 86$

VI. RESPONSIBILITIES AND EXPECTATIONS FOR

CIIILD's Counsel ............................ 864

VII. CONCLUSION: LAW SOCIETY AND

GovernMENT RESPONSIBILITIES . . . . . . . . . . . . . . . 869

\section{INTRODUCTION: \\ CONTROVERsy OVER THE ROLE OF ChILd'S COUNSEl.}

Since 1966, when counsel was first appointed as amicus curiae to represent a child's interests in a family law proceeding in Alberta, ${ }^{1}$ there have been dramatic changes in how children are perceived and treated in the justice system, but there continues to be uncertainty and controversy about the role and responsibilities for counsel appointed to represent the child. In a number of provinces and states, counsel for children in family proceedings have been given directions about their role and responsibilities, ${ }^{2}$ though there are differences in approach in different jurisdictions. In Alberta, however, counsel appointed to represent children in family proceedings do not have clear guidance as to their role and responsibilities. There continues to be controversy in Alberta over central questions in regard to the role of counsel for a child, in particular whether counsel is obliged to take instructions from a child and advocate based exclusively on those instructions, or whether there is a broader, nontraditional role that allows counsel to be guided by his or her own assessment of the best interests of the child.

This article discusses the different roles that may be adopted by counsel appointed to represent a child in a family proceeding: the child advocate, the best interests guardian or the friend of the court. I review different approaches to the resolution of the controversy over the role of counsel, with legislatures, courts, law societies and government departments playing a central role in different jurisdictions.

I argue that no role is appropriate for all cases, and that in Alberta, in the absence of a clear direction from the court, counsel for children must make their own decisions about the role that they will adopt, depending on the specific circumstances of the case. When deciding what role to play and how to represent a child, counsel must assess the child's capacity and, if the child has capacity, must advocate based on the child's instructions. If the child lacks

' Woods v. Woods, unreported 1966, Alberta Registry 41748 (Alta. S.C.T.D.), Manning J. For the history of child representation in Alberta, see Institute of Law Rescarch \& Reform, Protection of Children's Imerests in Custedy Disputes: Report No. 43 (Edmonton: Institutc of Law Research and Reform, 1984). For an article published a quarter-century ago that addressed this controversy in an Alberta context. sec M.J.J. Mcl lale. "The Proper Role of the Lawyer as Legal Representative of the Child"(1980) 18 Alta. L. Rev. 216.

: The primary focus of this article is on the role of counsel appointed by a court to represent children in child welfare proceedings and in cases involving separated parents under the federal Divorce Act. R.S.C. 1985, (2d Supp.), c. 3, or the Alberta Family Law Act, S.A. 2003. c. F-4.5. Cases where a minor directly contacts a lawyer to serve as an advocate for the position of the child raise issues that are beyond the scope of this article: sce Puszczak v. Puszczat (2005), 22 R.F.L. (6th) 147 (Alta. C.A.), 2005 ABCA 426 [Ptsszczak]. 
capacity to instruct counsel, then in deciding what role to play, counsel must consider the child's views, the nature of the case and such factors as whether the other parties are represented. I also discuss the responsibilities of counsel for children, and consider the implications both for the lawyer and the child of different roles that counsel may adopt.

A key issue is whether the child has the legal capacity to instruct counsel, as counsel is obliged to advocate based on the instructions of a client with capacity. The Code of Professional Conducl of the Law Society of Alberta provides that individuals only have capacity to instruct counsel if they can make "reasonable judgments respecting [their] affairs." I argue that this requires that counsel is to be satisfied that the child has the ability to exercise that judgment without undue adult influence and that the child has made a reasonable choice.

The article concludes with a brief discussion of some important issues that should be addressed by the government of Alberta and the Law Society if they are to meet their responsibilities to the children of the province. The child representation program in Alberta was quite large in the late 1980s, but in the early 1990s there was a change in government policy and a marked decline in the appointment of counsel for children. ${ }^{4}$ In recent years, however, sparked by a further round of changes in government policy, legislative reform and the Charler, ${ }^{3}$ there has again been an increase in the number of cases in which counsel are being appointed to represent children. While the government of Alberta is spending significant sums on child representation, primarily through Legal Aid, there is still not a wellorganized child representation program in the province, and significantly less is being spent on legal representation for children on a per capita basis than in some other provinces, like Ontario." It is time for the government of Alberta and the Law Society to coherently address a range of questions related to child representation, including the issue that is the subject of this article: the appropriate role and professional standards for counsel appointed to represent a child in family proceedings.

The Law Socicly of Alberta, Code of Professional Conduct (2 February 2006), online: Law Society of Alberta <www.lawsocictyalberta.com/files/code.pd\$, c. 9, C. 7.1 [Code] [emphasis added]. Judy N. Boyes \& M.E. (Peggy) Walden. "The Life and Death of the Amicus Curiae in Custody Litigation in Alberta" (1991) 8 Can. Fam. L.Q. 81. the Canada Act 1982 (U.K.), 1982, c. 11 [Charter].

Funding for child representation has been coming from difierent ministries and agencies, and this author was not able to ascertain how mucl is being spent. However, hased on presentations at the legal training programs on Child Representalion, in Edmonton on 1-3 April 2005, (infra note 63), it would secm that in 2004-05 about $\$ 1$ million was spent by the government on child representation in Alberta. This amount will likely increase in future years as a pilot program has been established in Calgary to provide representation for children whose parents are separated, and responsibility for child representation in child welfare proceedings is transferred to the office of the Child and Youth Advocate in the Ministry of Children's Services; see online: <www3.gov.ab.ca/cs/ocya/index.html>. 


\section{ROLES FOR COUNSEL: Friend of the Court, Guardian and Advocate}

While there is some variation in terminology, commentators have generally identified three ${ }^{7}$ possible roles for counsel appointed to represent a child: the friend of the court, the best interests guardian and the child's advocate. ${ }^{8}$ Some counsel for children quite consciously adopt one of these roles for all cases that they deal with, or at least have a consistent role throughout any given proceeding. Other counsel may adopt different roles at different stages of a proceeding. In practice, some counsel may consciously combine roles, while others may adopt a mixed role without much consideration of issues of professional responsibility. Despite the complex reality, it is useful to consider these three different roles, as the discussion provides a structure for considering how to deal with the issues that counsel for a child faces.

\section{A. FRIEND OF THE COURT}

In Alberta, when superior court judges first made amicus curiae appointments of counsel for children in custody and access cases in the 1960s, these lawyers were also expected to adopt a friend of the court role. ${ }^{9}$ Counsel adopting this role is expected to assist the court by ensuring that all of the relevant evidence is placed before the court and by making submissions to the court about legal issues that may arise. The focus of counsel's efforts is on ensuring that all feasible options for the care of the child are investigated, and that any relevant evidence that the parties have not introduced is brought before the court. Counsel who has adopted a friend of the court role should explain the court process to the child, if the child is old enough to understand, and should ensure that the wishes of the child, if expressed, are introduced in evidencc. Counsel adopting this role may retain a social worker or psychologist to investigate the case and, for example, to interview the child and provide evidence to the court about the child's wishes. This counsel is not, however, expected to

In a number of jurisdictions, professional rules now identify only wo possible roles, collapsing the guardian and the friend of the court into a single role. The American Bar Association distinguishes between the "Child"s Attorney" (advocate role) and the "Best Interests Attomey" (best interests guardian and friend of the court); sec American Bar Asseciation. Section of Family Law, "Standards of Practice for Lawyers Representing Children in Cuslody Casts" (2003) 37 Fam. L.Q. I31, online: American Bar Association <www.abanet.org/amily/reports/standards_childcustody.pdI>. In New South Wales, two similar concepts are used, but the distinction is drawn between the "Direct Representative" (or advocate) and the "Best Interests Representative"; see Law Society of New South Wales, Representation Principles for Children's Lamyers, 2d ed., (March 2002), online: <www.lawsociety.com.aw uploads/filelibrary/1038355147282_0.5690935283305489.pdis.

There is not a complete consensus about these three roles in the literature or case law; the discussion here is based on the author's assessment of how counsel adopting each of these roles should conduct himself or herself. For a further discussion of the three roles, see e.g. McHalc, stupra note 1; George $M$. Thomson, "Eliminating Role Confusion in the Child's Lawyer: The Ontario Experience" (1983) 4 Can. J. Fam. L. 125; and Runda Bessncr, The Voice of the Child in Divorce. Custody and Access Proceedings (Ottawa: Department of Justice, 2002).

" I use the English term "friend of the court" for the role that counscl may adopt, reserving the Latin term amicus curiae [also meaning "friend of the court"] for the legal jurisdiction to appoint counsel of a superior court judge under the parens patriae power; amicus curiae appointed counsel do not always adopt the "friend of the court" role, but sometimes adopt what I refer to as the advocate role or the best interests guardian role. Use of English terms is also preferable for counsel who are sceking to explain their role to children, parents and other lay persons involved in the court process. 
make submissions about what outcome or resolution would be in the best interests of the child.

Counsel adopting a friend of the court role may also have a neutral mediative role, attempting to facilitate a settlement, though if complex mediation is expected, the parties should be referred to a mediator.

Counsel adopting this role should make clear to the child and parties that what they say to counsel is not confidential, but may be shared with the court.

There are cases in which the friend of the court role is appropriate, but commentators, counsel and judges have argued that counsel will often be able to do more to benefit a child and the court than simply put forward evidence about the child.

\section{B. BEST INTERESTS GUARDIAN ${ }^{10}$}

In Alberta and elsewhere, lawyers appointed by the court as cmicus curiae or otherwise to represent a child have often adopted a guardian role, modifying the friend of the court role by adducing evidence about the child and advocating a position based on counsel's assessment of the child's best interests. " Counsel assuming this role undertakes the responsibility for ensuring that if the parties fail to introduce relevant evidence about the best interests of the child, they will do so. Thus, counsel will ensure that evidence about the child's views and wishes is placed before the court, often through a social worker or other witness, but counsel is not bound by any "instructions" that the child may give. While counsel may decide to advocate for an outcome desired by the child, counsel will only do so if satisfied that this will advance the child's best interests. Counsel adopting this role may introduce evidence about why the child's stated preferences are not truly independent but rather are a reflection of inappropriate parental manipulation, or can argue that the outcome desired by the child may not advance the child's interests. ${ }^{12}$

Although counsel adopting the best interests guardian role should meet with the child, counsel should make clear to the child that what is said will not be confidential, and that counsel is not advocating on behalf of the child. Such counsel may play an important role in helping the parties to resolve a case, attempting to ensure that the child's views and interests are reflected in any settlement.

This is sometimes referred to as a "guardian ad litem" role, though this term is not used in this paper as it is ambiguous, and often refers to a non-lawyer appointed to make decisions on behalf of a child in regard to civil litigation who may retain and instruct counsel.

There is much authority for counsel to take this role; see e.g. David C. Day, "Counsel for Christopher: Representing an Infant's Best Interests in the Supreme Court of Canada" (1983) 33 R.F.L. (2d) 16. explaining how, after appointment as amicus curine by the Supreme Court of Canada on its own motion. he adopted the role of best interests advocate for a five-year-old child whom he considered incapable of giving instructions; sec also Beson $v$. Newfoundland (Director of Child Welfore), [1982]2 S.C.R. 716. 
While the best interests guardian role is used by many counsel in Alberta and elsewhere, it is not unproblematic. Critics of this role on the Bench and among the Bar question what qualifies a lawyer to take a position about the best interests of the child. ${ }^{13}$ Is counsel not simply advocating based on their own personal opinions about what is best for the child? Critics also worry that counsel in this role may be too influential, both with judges, who may be tempted to effectively delegate responsibility for difficult decisions to counsel for the child, as well as with the parties, who may be unduly influenced by this counsel in their settlement discussions. It is also argued by critics of the guardian role that if counsel for the child is not advocating based on the child's expressed wishes, the child is without effective representation in proceedings that will profoundly affect the child's life. ${ }^{14}$

\section{ChILD's Advocate}

When counsel were first appointed for children in the 1960 s, these lawyers were not seen as having a traditional advocate's role, but increasingly it is being argued that for children who have the capacity to instruct counsel, counsel for a child should only advocate for a position based on the child's instructions. ${ }^{15}$ While counsel adopting the role of child advocate has the responsibility, as with any client, to explain the implications of different legal outcomes for the child, it is ultimately for the child to make decisions about his or her life and give counsel instructions about how to protect the child's interests and rights.

Counsel who adopts the role of child's advocate will treat the child as any other client, and in particular the child should be informed that what the child tells the lawyer will only be disclosed with the permission of the child. The one exception is that, if the lawyer learns that the child has been abused and may be placed in a setting where death or bodily harm (which includes sexual abuse) is likely to result, the Code of the Law Society of Alberta requires that

13 Sce e.g. cautionary comments about counsel for child making a best interests recommendation in Young v. Young (1985), 65 A.R. 347 [Young], Veit J. See also e.g. Martin Guggenheim, "Reconsidering the Need for Counsel for Children in Custody, Visitation and Child Protection Proceedings" (1998) 29 Loy. U. Chicago L.J. 299. In C.R. v. Children's Aid Society of Homilton (2004), 4 R.F.L. (6th) 98 (Ont. Sup.

C.) [Hamilion], Czutrin J. obscrved (at paras. 28-30) [emphasis added] [footnotes omitted]:

To the extent that counscl acting on behalf of a non-instructing client represents that child's best interests, and not his or her views and preferences, the Children's Lawycr arguably becomes "not the advocate of the children, but a protector of the children." In such a role - i.e., acting without clear instructions - prolecting the children's interests "can clcarly involve presenting the lawyer's pereeption of what would best protect the child's interests." I/ may become difficult to distinguish counsel's personal view's, even if moivaled by the child's best interests, from counsel's role as advocate. If the child is not instructing counsel, who is?

The problem for opposing counsel is the testing of the validity of these "instructions" where the Children's Lawyer represents a non-instructing client....

I do assume, however, that the social worker [retained by the Office of the Children's Lawyer] has made a preliminary assessment, based on best interests. It is for the children's counsel, ultimately, to present whatever evidence they have or to review the evidence and make submissions to protect the children's best interests. These should not be personal views, but based on a position the Children's Lawyer takes, based on the evidence and the law, to advance a position to protect the children. It is not for counsel to stand up and give personal views or to give cvidence from the counsul table.

See e.g. Judge A.P. Nasmith, “The Inchoute Voice" (1992) 8 Can. Fam. L.Q. 43.

Sec e.g. Leonard J. Pollock, "Representation of Children: The Alberta Experience" in Katherine Connell-Thouez \& Bartha Maria Knoppers, eds., Contemporary Trends in Family Law: A National Perspective (Toronto: Carswell, 1984) 189 at 200. 
counsel disclose this information. ${ }^{16}$ Thus, if a child tells her lawyer that she wants to live with her mother, despite the fact that she has been sexually assaulted by her mother's boyfriend, counsel is obliged to disclose the abuse if the child welfare authorities are not already aware of it.

The role of child advocate is now widely accepted as the only appropriate role for counsel who is representing an adolescent being dealt with under the Youth Criminal Jussice Act, ${ }^{17}$ or to provide representation for an adolescent in proceedings under the Protection of Children Involved in Prostitution Act. ${ }^{18}$ These are proceedings involving adolescents in which the state is seeking to restrict the child's liberty, albeit at least outside the YCJA context, with the objective of the promotion of the well-being of the child. These are also cases involving older children who have the capacity to instruct counsel, and will choose their own lawyer (from among those willing to accept the rates that government will pay for these cases). ${ }^{19}$

There is, however, continuing controversy about whether counsel may or must adopt the role of child's advocate in family law cases in which the court has directed that counsel is to be appointed to represent the "interests" of the child, as opposed to "representing the child" directly. Further, there are many child and family cases where counsel has been appointed for a child and the child is unable or unwilling to give counsel instructions; in these cases it will be impossible for counsel for a child to adopt the advocate's role.

There are also issues about how far child's counsel should go in sharing information with the child, even if counsel has adopted an advocate role. A lawyer representing an adult client is expected to share all information with the client. In the course of representing a child, counsel may learn information that would be emotionally damaging if shared with a child, or permanently harm a child's relationship with parents or other caregivers. A child's lawyer, for example, may learn from an assessment report about the circumstances of the child's conception, or about the true feelings of parents or relatives towards the child. In Alberta, if an assessment is prepared for use in the proceeding in the Court of Queen's Bench, "Family Law Practice Note No. 7" prevents disclosure of the report to the child without the permission of the court; this provision applies to counsel for the child and may constrain counsel who has adopted an advocate role. ${ }^{20}$

Code, supra note 3 at c. 7, R. 8(c). charged with criminal offences.

S.C. 2002. c. I [YCJA]. This stalute governs the proseculion of adolescents (aged 12 through 17 years)

R.S.A. 2000, c. P-28. This statutc allows for the apprehension and delention in "prolective safe houses" of youtlis under the age of 18 years who are believed to be engaging in prostitution.

In Calgary and Edmonton there are Youth Legal Aid Clinics, and youths facing charges under the $Y C: / A$ may be assigned a lawyer without having a choice of counsel. In practice. even in the clinies, youths may have a role in selecting a specific lawyer, and in any event have a right to chose to represent themselves. Court of Queen's Bench of Alberta, "Family Law Practice Note No. 7: Use of Independent Experts" (I April 2004), online: Alberta Courts <www.albertacourts.ab.ca/practicenoles/lamilylaw/note7.pdl>. 


\section{The Role of Counsel for the CHILd - The LEgal CONTEXT}

Counsel appointed to represent children in family cases may look to a number of possible sources for guidance as to the role that they should adopt. In different jurisdictions, the legislatures, the courts, the Law Society and government agencies have articulated rules to direct counsel for children about the role that they should adopt. In Alberta none of these authorities provides clear guidance about the role, leaving counsel for children with the individual responsibility for determining what role they will adopt.

\section{A. Legisl.ativf. DiRECTION}

It is possible for a legislature to give direction for the role that counsel for a child is to adopt. While this has been done in a few American states, ${ }^{21}$ politicians are generally more willing to enact laws to provide that counsel is to be appointed to represent children than to resolve the complex and contentious issues about the role that counsel is to adopt. It is, however, important for Alberta lawyers to be familiar with the different legislative bases for appointing counsel for children, and if they are appointed, to consider to what extent the legislation might guide their role and responsibilities.

If counsel for a child is appointed in an Alberta child welfare proceeding, it will generally be cases in Provincial Court, pursuant to the Child, Youth and Family Enhancement Act, which provides:

112(1) If an application is made for a supervision order, a private guardianship order or a temporary or permanent guardianship order, or a clild is the subject of a supervision onder or a temporary or permanent guardianship order or a permanent guardianship agrecment.... the Court may direct that the chlld be represented by a lanyer if

(a) the child, the guardian of the child or a director requests the Court to do so, and

(b) the Court is satisfied that the interests or views of the child would not be otherwise adequately represented. 22

This section indicates that the lawyer is to "represent" the child's "interests or views," leaving open the question of what role counsel is to play in the proceedings. As discussed below, at the time that a judicial direction is made that representation is to be provided, the court may give instructions about the role that counsel is to play, although in practice this will rarely be appropriate.

21 See Frank E. Vandervort. "Representing Children in Protective Proceedings: Learning From Michigan's Experience" (December 2000) 19:10 ABA Child Law Practice 153, discussing MCLA 712A.17d (enacted 1998).

$22 \quad$ S.A. 2004, c. 16, amending R.S.A. 2000, c. C.12 [emphusis added]. Further, s. 2 provides:

(d) a child who is capable of forming an opinion is entitled to an opportunity to express that opinion on matters affecting the child, and the child's opinion should be considered by those making decisions that affect the child;

Section 11 l(2) provides that a child is a "party" to a child protection or secure treatment proceeding. 
Judges in the Provincial Court in Alberta dealing with custody and access applications sometimes use the Provincial Court Act s. 18(6)(b) to have counsel appointed for a child, though this section does not explicitly provide for such an appointment:

18(6) The application for an order under this section may he made

(a) by either parent of the child, or

(b) by the child, who may apply with or without any person interested on the child's behalf. ${ }^{23}$

This provision allows the court to appoint counsel to act "on behalf of a child." In theory, a child may seek to become in effect a party to a proceeding under this provision, in which case a lawyer directly retained by the child client should act in an advocate role, though in practice this rarely (if ever) happens.

The new Alberta Family Law Act deals more explicilly with court orders for the representation of children who are the subject of a custody or access dispute, providing: ${ }^{24}$

95(3) The court may at any time appoint an individual to represem the interests of a child in a proceeding under this Act.

(4) Where the court appoints an individual under this section, the court shall allocate the costs relating to the appointment among the parties, including the child, if appropriate. 25

This provision in the Fumily Law ACt, which speaks about the representation of the interests of a child, might seem most consistent with counsel adopting the role of best interests guardian, but it is submitted that this statement is too vague to preclude counsel from adopting either the advocate role or the friend of the court role, as these roles also involve representation of the interests of a child. It is significant that s. 95(3) does not refer to the representation of a child's "best interests," suggesting that counsel has significant discretion as to how to define the concept of the child's "interests."

It is submitted that none of the Alberta legisiative provisions that allow for appointment of counsel for a child provides clear guidance for the role that child's counsel is to adopt.

\section{B. JUDICIAL DiRECTION}

In a number of jurisdictions the courts have rendered decisions on the role that they expect counsel for a child to play, though in Alberta there has not been clear guidance provided by the judiciary.

R.S.A. 2000, c. P.31.

$\therefore$ Family Law Act. S.A. 2003, c. F-4.5. in forec I October 2005. Alberta L.cyal Aid may pay for counsel for a child if the parents are unable to provide representation. In Edmonton, such representation may he provided by the Family Law Legal Aid Clinic. In Calgary, there is a pilot program to provide representation lor children whose parents are separated. 
Shortly after a program for representation for children involved in protection proceedings was established in Ontario in 1978, judges in that province expressed conflicting views on their expectations for counsel for a child. Judge Karswick, for example, in $\operatorname{Re} C_{.}^{26}$ supported counsel's decision to adopt the role of best interests guardian, writing:

I do not think that the court can, nor should it, direct the child's counsel to take a strict adversarial rolt and act as a "mouthpiece", blindly advocating a view, preference or instructions which confound or shock his professional opinion of what is in the best interest of the child. It makes eminently good sense to have counsel take an active, real and positive role in the social context of the family court ... assume the obligation to adduce all relevant and malerial evidence on the issue of what is in the best interest of the child and, when called upon, to express a professional and responsible view of what that disposition should be. [Counsel for the child is] ... permitted ... to state the views and preferences of these two girls ... and, in addition, to state what, in his professional view, was the disposition which would be in the best interest of the children and his reasons for advocating that position as supported by the cvidence. ${ }^{27}$

By way of contrast, Abella, Prov. Ct. J., (as she then was) in $R e W^{28}$ held that counsel appointed to represent "the interests of a child" should adopt the child advocate role, writing:

[E]ssentially the role of the lawyer for the child is no different from the role of the lawyer lor any other party: He or she is there to represent a client by protecting the client's interests and carrying out the client's instructions....

There is a tendency to assume that the quintessential legal representative for the child is, or should be, a paragon of legal, psychological and sociological expertise. This is unrealistic. Lawyers generally have only legal skills, the proper utilization of which may undoubtedly involve some direct or indirect fumiliarity with or reliance upon other disciplines... Lawyers for children can therefore be expected to do no more and no less than any other party's lawyer in the adversarial process....

Representing a client in these cases usually involves executing a client's instructions and ... attempting to show through the evidence that these instructions or wishes best match the child's needs. ${ }^{29}$

The Ontario courts have not definitively resolved the issues of the role that counsel for children in that province are to play, though as discussed below, as a result of government policy in that province. lawyers appointed to represent children in family proceedings now adopt the best interests guardian role.

The Quebec Court of Appeal, in its 2002 decision in M.F. v. J.L. ${ }^{30}$ made clear that lawyers appointed to represent children in family proceedings are to adopt the advocate role,

(1980), 14 R.F.L. (2d) 21 (Ont. Prov. Ct. (Fam. Div.)).

Ibid. at 25-26.

(1979), 13 R.F.L. (2d) 381 (Ont. Prov. Ct. (Fam. Div.)).

Ibid. at 382-83.

(2002), 211 D.L.R. (4th) 350 (Qc. C.A.) [MFJL]. leave to appeal to S.C.C. dismissed without reasons [2002] C.S.C.R. No. 218 (QL). A Quebee Bar Commitlee Report was cited and influential with the Court: Barreuu du Quśbec, Comité du Barreau sur la représentation des en lants par avocat, Mimoire sur la représentation des enfants par avocar (Montréal: Service de la formation permanente du Barreau du Québec, 1995). For a translation of an earlier Consultation Paper in Quebec, see Quebec Bar Committee. "The Legal Representation of Children" (1994) 13 Can. J. Fam. L. 49. 
as long as the child is giving clear instructions. The case involved a dispute between the parents of a "mature" child, almost ten years of age when his parents separated. The parents were involved in acrimonious litigation about whether the father would have access to the child. With the consent of both parents, counsel was appointed to represent the child. The child's counsel retained a psychologist who interviewed the child. The boy told both the lawyer and the psychologist that he did not want to see his father, but the psychologist concluded that the boy's antipathy towards his father was due to "parental alienation syndrome," induced by the child's mother. Counsel initially appointed for the child advocated based on the child's wishes, arguing that access should be terminated, but the trial judge ordered that counsel was to be replaced by a second lawyer who was expected by the court to develop her own position about the child's best interests. The mother appealed the judge's order appointing second counsel, arguing that second counsel for the child should be replaced by a lawyer who would advocate based on the child's expressed wishes not to see his father. The Court of Appeal agreed with the mother, ruling that even if counsel is appointed to represent the "interests" of a child, that counsel is expected to adopt an advocate's role if the child has the capacity to express wishes and is expressing a clear preference. Justice Rothman wrote:

[1] a child is sufficiently mature to express himself on a vital question such as custody or access by his parents, then he has the right to be heard on that question and the right to have his wishes fairly put in evidence before the court. If the child has the capacity and the desire to express his wishes, then that is a fundamental right that must be respected by counsel who represents him, whether or not counsel may have a different personal opinion on the malter...

Counsel representing a child capable of expressing his wishes does have ... a professional right and duty to advise the child as to the possible consequences of the wishes expressed by the child and to counsel the child as to what counsel feels is in the child's best interest.

But in the end, the child has a right to have his own wishes heard by the court and advanced. And in the end, counsel for the child has a professional duty to assure that the child's wishes are heard and his rights are respected. whatever her personal opinions are in the matter. That was the reason for her appointment in the first place and that is the function of an advocate in our justice system. ${ }^{31}$

The Quebec Court of Appeal decision in M.F. v. J.L. gives a clear direction that is applicable to counsel representing children in that province in family cases. It is significant that the Court accepted that if a child has "the capacity and the desire to express his wishes," this must guide counsel. As will be more fully discussed below, this is a low standard for assessing capacity, as there is no need for counsel to assess whether the child has the capacity to make "reasonable judgments" or has formed independent opinions. It is sufficient for the child to be able to express his or her wishes.

In the 1989 Alberta child protection case of $R e A .{ }^{32}$ Fitch J. took a quite different approach from the Quebec Court of Appeal, accepting without criticism the best interests guardian role adopted by counsel for three children, aged 8,11 and 12: 
Counsel appointed for the children supports the director's application, although all three children have expressed a desire to return to live with their mother. While s. 78 of the Child Welfare Act provides that the court appoints a lawyer to represent a child if the court is satisfied that the interests or views of the child would not be otherwise adequately represented, it is common practice for counsel appointed pursuant to $\mathrm{s}$. 78 to form their own opinion as to what is in the best interests of the children. even though that position may differ from the views of the clients, the children. ${ }^{33}$

While no court in Alberta has rendered a definitive judgment about the appropriate role of counsel for a child, there are cases in which judges have expressed views about the appropriate role for counsel appointed as amicus curiae by the Courl of Queen's Bench in a custody or access case. In Young, Veit J. wrote:

The role of the amicus is to provide assistance to the court in arriving at a custody decision. $h$ is not specifically ordered that the amicus is to represent the children who are the subject of the custody disputte and to sake instructions from them. Although that is presumably one mode of assistance potentially available. the usual order of appointment does not specify how the amicus is to assist the court, nor whom it is to represent.

Although the trial judge has discretion as to the way in which a trial is conducted, it may be difficult to exercise that discretion when all pre-trial matters have evolved in a specific way. It might be useful. therefore, when applying for the appointment of an amicus, winform the court of the specific role one wishes the amicus to perform. If the amicus is to act as a guardian ad litem, for example. perhaps it should become a party in the proceedings. sign a Certificate of Readiness, be consulted about trial dates, be subject to discovery, comply with rules relating to the exchange of expert's reports, etc. If the amicus is to act as a teclunical resource to provide an expert opinion, it should not be considered as a party, nor have a right to cross-examinc, elc. ${ }^{34}$

This decision suggests that, at the time of appointment, the court may give directions as to the role that counsel is expected to adopt, for example by requiring counsel to only take a "friend of the court" role and to refrain from advocating any position. ${ }^{35}$ It seems logical that if a superior court judge is exercising the inherent parens patriae judicial power to appoint an amicus curiae, the court should have the power to specify the role of counsel in order to meet the objectives of the court in appointing counsel. Further, given the vagueness of Alberta's legislative provisions for the appointment of counsel for children, courts invoking one of those statutory provisions should also have the authority to specify the role that counsel is to play. However, in practice, at the time of appointment, the judge is not likely to have much information about the case, so that it will rarely be appropriate for the court to direct counsel about the role that he or she is to play.

As discussed above, some judges in Canada have ruled, at the time of trial, about the role that they expect counsel to adopt, and counsel would presumably be bound by any such direction. In practice, in Alberta, judges have been prepared to allow lawyers to determine the role that they will play. 
There may be cases in which counsel appointed for the child will want to seek directions from the court about the role that he or she is to play in a case. Such directions may help counsel and all involved to be clear about the role of counsel, or may help to resolve an ethical dilemma, for example if the child and counsel disagree about the role that counsel is to adopt.

\section{L^w SOCIETY RUI.eS}

In a number of jurisdictions, law societies have directly addressed the question of the role of counsel for children in family proceedings.

The Law Society of New South Wales in Australia, for example, has explicit and detailed professional rules on child representation, including a statement that a lawyer shall act as the "direct representative" (advocate) for a child unless the "law clearly states that the representative shall play a different role in representing the child; or the practitioner determines that the child is incapable of giving instructions. ${ }^{* 36}$ It is interesting, however, to note that in cases of parental separation in New South Wales, the statutory provisions clearly give counsel for a child a broad mandate to advocate a position based on the best interests of the child rather than taking instructions from the child."

In 1981, the Professional Conduct Committee of the Law Society of Upper Canada established a Sub-committee on The Representation of Children, which concluded that lawyers appointed to represent children in family proceedings should follow the traditional advocate's role, provided that a child has the capacity to instruct counsel. The Sub-committee qualified this position, however, by positing that the failure of a child to follow counsel's advice might be the basis for concluding that the child lacks the capacity to instruct counsel, and for counsel to fail to follow the child's directions:

[A child may be deemed to have capacity where] the child is mature and responsible enough to accept the consequences of his or her acts and decisions and ... can express a prelenence as to its resolution.... One of the factors ... in making this decision would be the ability of the child to accept rationally the advice he or she is reciving. If the child sibhornly, without reason. refuses to accept the advice of commsel, it may be that the child lacks the maturily to properly instruct counsel. ${ }^{38}$

This last qualification could give counsel significant discretion to disregard the expressed wishes of a child if counsel has concerns about the plan that child wants, by concluding that the failure to follow the advice of counsel reflects incapacity to instruct counsel. Further, as discussed below, this report no longer guides the representation of children in Ontario, although the Law Society in that province has never formally withdrawn this policy.

" Re K. supro note 35. Sec also Family Court of Australia, Guidelines for The Child's Represcmentive (Drift 25 May 2003), online: <www. familycourt.gov.au/presence/resources/file/cb0(0)/4b20855701/ guidelines01.pulls.

is Law Society of Upper Canada. "Report of Sub-committec on The Representation of Children" in Nicholas Bala, Heino Lilles \& George Thomson. eds., Camadian Chiltren's Law: Cases, Notes and Materials (Toronto: Butterworths, 1982) 240 at 240-41 [emphasis added]. 
The Code of the Law Society of Alberta states that only in "some circumstances" should counsel take instructions from a child, stipulating that individuals are only legally capable of instructing counsel if they can make "reasonable judgments respecting [their] affairs." The Law Society Code also indicates that if a client is lacking in capacity, counsel should "act in the best interests of the client" until a personal representative (such as a guardian ad litem) is appointed by the court. These rules from the Law Society of Alberta were clearly drafted for use in more traditional areas of practice, in particular for cases involving financial and property matters, where it is possible to seek the appointment of a guardian ad litem who can then instruct counsel in the litigation, a step that is not possible in family proceedings. Alberta, unlike jurisdictions such as Quebec, Ontario and New South Wales, has not directly addressed the role that counsel for a child is expected to play in family proceedings, though as will be discussed more fully below, the present Code does provide counsel for children with some important guidance.

\section{Government Policy}

In Ontario, the Office of the Children's Lawyer, a government agency that is part of the Ministry of the Attorney General, is responsible for providing counsel for children in civil and family cases. It has a number of staff lawyers, but most of its representation is provided by lawyers in private practice who are recruited to serve as lawyers for children. In 1995 the Office of the Children's Lawyer drafted its own policy on the Role of Child's Counsel. Unlike the Ontario Law Society policy, which favoured the advocacy role, the Office of the Children's Lawyer adopts the best interests guardian role for counsel for the child. Counsel for the child is to ensure that the court is made aware of the wishes and preferences of the child, but counsel may decide to advocate for a position that advances the interests of the child, even if that position is not consistent with the wishes of a competent child. In deciding what position to advance, counsel should have regard to the "independence, strength and consistency of the child's views," but is not bound by those views. The Policy Statement of the Ontario Office of the Children's Lawyer provides:

\section{ROLE OF CHILD'S COUNSEL}

Duty and Status of Child's Counsel

... counsel reviews information and advectes a position for the child clicm....

Position on Behalf of the Child

In taking a position on behalf of the child, child's counsel will ascertain the viens and preferences of the child. if any, and will consider:

(a) the independence, strength, and consistency of the child's views and preferences,

(b) the circumstances surrounding the child's views and preferences, and

(c) all other relevant evidence about the child's interests. 
In a child protection proceeding, child's counsel may tuke a different position than the other parties, even where the parties all agree upon a position. However, in custody/access proceedings, child's counsel will not interfere with a settlement reached by the parties.

\section{Contested Hearing}

If it is necessary for the court ... to determine ... disputed issues, counsel will advocale a position on behalf of the child and ensure that evidence of

(a) the child's views and preferences,

(b) the circumstances surrounding those views and preferences, and:

(c) all other relevant evidence about the child's interests. is before the court."

Although this policy of the Office of the Children's Lawyer is not consistent with the advocacy role put forward by the Law Socicty in 1981, the Policy on the Role of Child's Counsel of the Ontario Children's Lawyer now guides counsel in Ontario, who are screened, trained, supervised and paid by this government oflice. The Children's Lawyer Policy has also been accepted by the judiciary in Ontario as an appropriate guide for lawyers for children, and thus has effectively superseded the earlier Law Society policy."2

\section{Capacity to InStruct COUNSEL}

It is submitted that in Alberta, in the absence of a clear direction from the court at the time of appointment, the Law Society Code requires that counsel appointed for a child in a family proceeding should adopt the advocate's role if, and only if, satisfied that the child has the legal capacity to provide instructions. Further, if the child has capacity to instruct counsel, then counsel is obliged to adopt the advocate role, unless directed by the court to play a different role. This makes the standard for determination of whether a child has capacity to instruct counsel a very important question to address in the representation of children.

A wide range of differing standards for assessing the capacity of a child to instruct counsel have been proposed. Some, like the late Ontario Judge Peter Nasmith (writing in an article), have argued for a low standard, positing that if a child is able to communicate views about the matters at issue, these views should guide counsel, who should not "second guess" the child. ${ }^{43}$ Judge Nasmith suggests that unless they are developmentally delayed, children of four or five years of age should be able to instruct counsel. As discussed above, the Quebec Court of Appeal, in its 2002 decision in M.F. v. J.L., ${ }^{\text {th }}$ also adopted this low standard for assessing capacity; it is sufficient for the child to be expressing wishes. Others, like Ontario lawyer Jeffrey Leon, have proposed a high standard, namely that a child must be "able to appreciate the nature and purpose of the proceedings, the alternatives available to the Court,

Policy of 3 April 1995, last revised I April 2006 [emphasis added].

For an example ol an Ontario case where the court approved of counsel for the child advocating a different position from the expressed wishes of the child because ol concern about manipulation of the child by one parent, see Boukema, supra note 12. In Ilamilton, supra note 13. Czutrin J. held that counsel for a young child who was incapable of giving instructions was entitled to advocate for a position "based on the evidence and law" that protects "the children's best interests."

Nasmith, supra note 14 at 55.

MFJL, supra note 30. 
the risks to him if he is permitted to remain at home, and ... [have] sufficient maturity to weigh these factors with a reasonable degree of dispassion and objectivity." 45

In Commentary 7.1 of the Code, the Law Society of Alberta adopted a standard that is clearly higher than that articulated by Judge Nasmith and the Quebec Court of Appeal, stipulating that individuals only have capacity to instruct counsel if they can make "reasonable judgments respecting [their] affairs." This requires that counsel is to be satisfied that the child has made "a reasonable choice," and that the child has excrcised his or her "judgment" without undue adult influence. The Alberta Court of Appeal in Puszczak v. Puszczak overturned an order appointing a lawyer who had been contacted and paid by the father to act for his 12-year-old son in a custody variation dispute, based on counsel's lack of independence; in obiter dicta the Court suggested that in order to have the legal capacity to instruct counsel, the child must "be capable of making reasonable choices and can exercise judgment without undue adult influence."N7

Some legislation makes 12 an important presumptive age for establishing certain types of legal capacity; in particular, the $Y C J A$ establishes 12 as the minimum age of criminal responsibility, and the Alberta Child. Youth and Family Enhoncement Act provides that a child of 12 or older should receive notice of a protection application. ${ }^{48}$ Some authors, like Leon, have suggested that there should be a presumption that children 12 and older have the capacity to instruct counsel. I would submit, however, that in family related proceedings, counsel appointed for a child should make an individualized assessment, without a presumption of capacity at any fixed age. If counsel is not satisfied that the child has capacity, counsel should treat the child as lacking in the legal capacity to instruct counsel. Even if the child lacks the legal capacity to instruct counsel, the child's wishes and views should always be communicated to the court and, depending on the circumstances, may influence the approach of child's counsel.

\section{ASSESSING CAPACITY AND DETERMINing Role.}

Absent a specific direction at the time of appointment, counsel appointed to represent a child in a family proceeding in Alberta must make a decision about an appropriate role based on the facts of the specific case. If the counsel determines that the child has capacity to instruct counsel, then the advocate role should be adopted. If the child lacks capacity, then, depending on the nature and circumstances of the case, counsel should adopt the role of friend of the court or best interests guardian; the views of the child should always be presented to the court, and in some cases may guide the advocacy position of counsel, even if a best interests guardian role is being adopted.

Jeffrey S. Leon. "Recent Developments in Legal Representation of Children: $A$ Girowing Conecrn with the Concept of Capacity" (1978) I Can. J. Fam. L. 375 at 4II, citing Jonathan Dick. "The Role of Counsel in Neglect and Dependency Proeedings" in Jwenile Cours in Transition - A Workshop, 49w Annual Legal Aid and Defender Conference (Denver, Colo., 5 November 1971). 
The Code of the Alberta Law Society provides that individuals are only regarded as able to instruct counsel if they can make "reasonable judgments respecting [their] affairs." This requires counsel to determine whether the child has the cognitive and psychological ability to make a judgment. Counsel should be satistied that the child has made "a reasonable" choice; counsel does not need to be satisfied that the child is making a decision that accords with counsel's view of the child's best interests, but should be satisfied that the child's desired position is not "unreasonable." A decision that will likely harm the child is clearly not reasonable. A decision that only serves to achieve short-term objectives is not reasonable. Further, counsel must be satisfied that it is the child's judgment that is being exercised, and that the child is not merely stating what a parent or other influential adult wants. As stated by the Alberta Court of Appeal in Puszczak, the child must be exercising "judgment without undue adult influence" ${ }^{\prime 0}$ if counsel is acting on the child's instructions.

If a child is frequently changing his or her mind, or if the child's instructions are confusing or inconsistent, or if there is a significant risk of serious harm in the desired plan, counsel should conclude that the child lacks the legal capacity to instruct counsel. While in this case, the views of the child should be communicated to the court. counsel should not adopt the advocate role.

Even if adopting an advocate role, as discussed below, counsel who has been appointed by a court to represent a child in family proceedings may have somewhat broader responsibilities than counsel for an adult client. However. counsel who has adopted an advocate's role cannot breach solicitor-client privilege by revealing the child's confidences without the child's permission (unless, as discussed above, there are immediate abuse concerns). ${ }^{31}$ In some cases, this may require counsel to retain a psychologist to determine whether the child is the subject of "alienation" or manipulation by a parent, and is subject to "undue adult influence."

If counsel is not satisfied that a child meets the legal test of capacity to instruct or if the child is not giving instructions, counsel may take the role of best interests guardian, advancing a position based on counsel's assessment of the child's best interests, but also ensuring that all relevant evidence is before the court, including evidence of the child's wishes. This is consistent with the Law Society Code's directions to "act in the best interests of the client" lacking in capacity. Counsel appointed to represent children lacking in capacity or providing no instructions may decide that they are not in a position to make a best interests recommendation, and may adopt the friend of the court role as the most appropriate way to advance the child's interests and simply ensure that all evidence is before the court.

Some children may have the communication skills, cognitive capacity and judgment to instruct counsel, but may be unwilling to do so. Some children have a profound distrust of strangers and may not be willing to express their wishes and views to counsel. Counsel for a child will have to take the time to develop a relationship with the child and to explain the issues in a meaningful way to the child. Counsel will have to take the time to develop a 
relationship of trust with a child, which may be especially challenging if there are cultural or linguistic differences between counsel and the child. Some children will only make their position clear to counsel after several meetings.

In many cases, particularly those involving parental separation, children have the cognitive capacity to understand the issues, but are ambivalent or are unwilling to express their views. ${ }^{\text {s2 }}$ Children may be reluctant to express their views for fear of causing emotional pain to one or both parents. Another related concern, especially in high-conflict cases, is that intentionally or unintentionally one or both parents may create feelings of guilt or fear in the children, which results in children masking their true feelings. As noted by one prominent American psychologist:

[T]here are ... children who refuse to give statements and express custody wishes, or children's verbal expressions may be contrary to their real feelings and represent discrepant statements because of ambivalence and loyalty confliets, massive hostility between the dispuling parents or parental pressure. ${ }^{53}$

Cases in which children are ambivalent or caught between two warring parents are not only difficult for lawyers and the courts, they also pose great emotional risks for the children involved:

One of the most pathogenic dynamics of the typical (high conflict) custody dispute is that ... the child becomes the object of intensive lobbying by parents who feel compelled to convince ... [the child] of their own innocence, their spousc's guilt, or their view of life in general. The child has few defenses against this dynamic. One who prolests, who expresses doubt or seepticism to a parent, may be berated for betrayal; one who is not so accused may view himself or herself as a traitor. ${ }^{54}$

These are cases in which one (or both) parents are engaging in "alienating" behaviour. It should, however, be appreciated that sometimes a parent who is engaging in alienating behaviour is not consciously trying to destroy their child's relationship with the other parent or influence what the child will say to counsel. Parents in high conflict cases may fail to fully appreciate the effects that their hostile attitudes are having on their children. ${ }^{55}$

Some mental health professionals argue that the direct involvement of children in disputes between their parents can be emotionally destructive, especially for pre-adolescents, as children may be fearful of being disloyal to one or both parents if they are forced to make a custodial choice. ${ }^{36}$ American child psychologist Dr. Richard Warshak discusses the dangers

Sec e.g. Children's Aid Society of Ottanta v. J.A. (2004), 132 A.C.W.S. (3d) 1109 (Ont. Sup. Ct.), Toscano Roecamo J., a child protection case in which the children expressed "diverse attitudes towards contact with their mother" at different points in time, characterizing their statements as "wishes "in the moment"' (at paras. 385-86). Karl-Franz Kaltenborn, "Individualization, Family Transitions and Children's Agency" (2001) 8 Childhood 463 at 487. Behavioral Sciences \& the Law 399 at 407. 
of asking children whose parents are going though a high conflict separation about their preferences. He argues that there is a need

to recognize the tension that exists between empowering children and placing them in the middle of their parents' disputes. The more weight accorded children's stated preferences, the greater the risk of children being manipulated or pressured.... [Asking children about their preferences] risks creating a climate that pressures a child to form a pathological alignment with one parent and a pathological alienation from the other. Rather than participating meaninglully in developing an optimal parenting plan or being empowered, the child is stripped of a genuine voice; the child's voiec is dubbed with the words of the parent who exereises the most influence over him or her. Another problem with ... involving children in litigation is that [this can] ... sel up a dynamic that can weaken a parent's authority over his or her children and can undermine the children's mutivation to resolve conflicts with a parent. ${ }^{57}$

A sensitive interviewer, whether a lawyer, a social worker or a judge, will often decide that it is preferable not to confront a child, especially a younger child, with direct questions about "choosing" which parent to live with, but rather will allow the child's views and preferences to be revealed more indirectly. Children with strong and clear preferences will invariably make them known, even if questioning is indirect, while children with loyalty conflicts may be distressed by direct questions, and may not provide answers that accurately reflect their true feeling, or may not give consistent answers.

The United Nations Convention on the Rights of the Child, ${ }^{58}$ the common law and legislation make clear that courts must consider the views of children when making decisions about children, but children should not be pressed to express their views if they are reluctant to do so. Counsel for a child has a responsibility to protect the rights and interests of a child, including the right not to be pressured to express preferences about living arrangements.

Sec e.g. Richard A. Warshak, "Payofts and Pitfalls of Listening to Children"(2003) 52 lamily Relations 373 at 375.

United Nations, Convention on the Rights of the Child (1989) 28 I.L.M. 1456 [Convemtion], recognizes the importance of the views of the child and representation for children in judicial and other proceedings affecling them, and articulates this in Ierms of the rights of the child:

An. 12(1): States Parties shall assure to the child who is capable of forming his or her own views the right to express those views freely in all matters affecting the child, the views of the child being given due weight in aceordance with the age and maturity of the child.

Art.12(2): For this purpose, the child shall in particular be provided the opportunity to be heard in any judicial and administrative procecdings affecting the child, either directly, or through a representative or an appropriate body, in a manner consistent with the procedural rules of national law.

The Convention, however, like Canadian law, also recognizes that decisions about children are to be based on their "best interests," with an. 3 articulating as a central principle:

An. 3(1): In all actions concerning children, whether undertaken by public or private social welfare institutions, courts of law, administrative authorities or legislative bodies, the best interests of the child shall be a primary consideration.

As a malter of law, there are limitations on the potential of the Comvenion to affect the oulcome of cases in the Canadian courts. However, the ratification of the Comvention by Canada provides at least symbolic recognition of the imponance the rights of children and of the promotion of their best interests and of advocacy on their behalf. Further, there are cases in which Canadian courts have cited and relied on the Convention as a guide to statutory interpretation to promote the interests of children: see $e . g$. Baker v. Canada (Minister of Cilizenship and lmmigration), [1999] 2 S.C.R. 817; V.L. v. D.L. (2002), 293 A.R. 104, 2001 ABCA 241: and Jutta Brunnée \& Stephen J. Toope, "A Hesitant Embrace: The Application of International Law by Canadian Courts" (2002) 40 Can. Y.B. Int. L. 3. 
Once counsel has assessed a case and determined what role to play, counsel should be clear with the child, the parents, the court and others involved in the case about the role adopted, and the consequences of the adoption of that role. Until counsel has made a determination about the role that will be adopted, counsel should be investigating and assessing a case, and protecting the rights and interests of a child, without making any firm commitments about such issues as confidentiality.

\section{RESPONSIBII.ITIES AND EXPECTATIONS for CHILd's COUNSEl.}

A number of professional organizations outside Alberta bave developed standards to provide direction for counsel for children. While there is some variation among the different standards developed by such bodies as the American Bar Association, ${ }^{39}$ the Law Society of New South Wales ${ }^{60}$ and the Ontario Office of the Children's Lawyer, ${ }^{61}$ there are also some common themes. Drawing on these different standards, I propose the following as professional guidelines for lawyers in Alberta who are appointed by a court to represent a child in family related proceedings, though recognizing that each case is unique and the role that counsel adopts will affect the handling of a case:

- Training and Knowledge of Resources: Counsel for a child has the responsibility to have appropriate preparation before representing these most vulnerable clients in these most sensitive cases. This type of work requires not only awareness of relevant legislation and jurisprudence, but also an understanding of child development issues, knowledge of local resources and development skills for interviewing and advising child clients.

- Accepting Appointment: Children are vulnerable clients and typically play no part in selecting counsel. Counsel should only undertake to represent a child if counsel believes, on the basis of information provided when the request for representation is made, that he or she is competent to represent the clild. During the initial phase of involvement, counsel may learn about issues or aspects of the case that raise concerns about his or her competence or capacity to provide adequate representation, in which case counsel should ensure that another competent lawyer is appointed to represent the child.

- Maintaining Independence: Counsel for a child must be independent from the parents and any other participants in the proceedings, taking directions only from the court, and instructions only from a child with capacity. It is important not only that it is independent, but that the perception of independence is maintained. Ordinarily, counsel can represent siblings, even if they have different desired outcomes, but there may be cases where counsel is adopting an advocate's role and conflicts arise between the positions of siblings which will require separate representation. In litigation between parents, counsel for a child should not become involved in a case without both parents being informed prior to 
the appointment of counsel..$^{62}$ In the absence of a court order, it is never appropriate for counsel for a child to be paid by only one parent.

- Communicating with Parties: In order to maintain the appearance of independence, counsel for the child should make an effort to ensure that all parties are treated in a fair, courteous and impartial fashion. Counsel for the child must avoid being seen to be "allied" with one party. Generally, communications with one party are shared with any other party.

- Review of Doctments and Reports: Prior to taking a firm position about a case, counsel should review the court file, including any pleadings and reports, and should contact other counsel for copies of relevant documents in the possession of the parties and for permission to obtain relevant documents in the possession of third parties.

- Meting with the Child: Even if certain that the child will not have capacity to provide instructions, counsel should meet with the child to gain an appreciation of the child's stage of development, personality and needs. If the child is old enough to communicate meaningfully with counsel, let alone competent to provide instructions, counsel should meet with the child at least three times in order to develop a good communicative relationship with the child and to be in a position to assess the strength and consistency of the child's wishes. Interviews with children should be held in locations that children will consider safe and comfortable. Depending on the nature of the case and the age of the child, it may be appropriate to meet the child before having any other involvement in the case; alternatively, counsel may decide to review documents and meet with the other parties in order to have a proper orientation before meeting the child. ${ }^{63}$ An older child may feel more engaged and respected if counsel meets with the child prior to meeting with others involved in the case.

- Communication with the Child: Counsel should communicate with the child in a way that is appropriate to the child's age, level of education, cognitive development, cultural

In Puszczok. supra nole 2, a father took his 12-year-old son to a lawyer, without the mother's knowledge; the parties had joint custody with the mother having primary residenes. The lawyer interviewed the boy and apparently concluded that the child had capacity to instruet counsel; the boy expressed a desire to alter child care and school arrangements so that he could move from Calgary to Edmonton to live with his father. The lawyer was sending his bills to the father and, at the ehild's request, the mother was nol infurmed of his retainer for several months. The lawyer obtained a courn order appointing himself as counsel for the child, a decision reversed by the Alberta Court of Appeal, with Paperny J.A. commenting:

If counsel is to be appointed for the child, it is imperative that the counsel, at the outset, be frec from the appearance of alignment with the position of one of the parents. This is particularly so where the child's interests may conflict, at least on the face, with the interests of one of his or her parents.

... While the child apparently expressed his preference to continue with the lawyer ... the chambers judge failed to appreciate that the appearance of bias would exacerbste the conflict, promote further linigation and diminish any pospecr of an amicable resolution (at paras. 28-29 [enphasis added]]).

Some counsel al ways have an initial meeting with the child, just as they would with an adult client, prior to reviewing any documents or meeting with any other individuals involved in the case; see Victoria Adamson. "The Role of Children's Counsel and the Etiquette of Independence" (Paper presented at the legal training programs on Child Representation, Edmonton, 1-3 April 2005 and Calgary, 15-17 April 2005) at Tab 4. 
background and degree of language acquisition, if necessary using an interpreter (who is not a family member). In an age and developmentally appropriate fashion, the lawyer should inform the child about the court system, the proceedings and the lawyer's responsibilities. The lawyer should always attempt to elicit the child's views and keep the child informed about the progress of the case. Children should be interviewed in a sensitive fashion, with counsel making clear that they are not obliged to express opinions or views about such issues as where they want to live, though also making clear that they may do so if they wish. Counsel must avoid making any commitments to the child that cannot be honoured. Even if counsel decides that the child lacks the capacity to instruct counsel and hence solicitor-client privilege is not directly applicable, counsel should be very careful about not prejudicing the child's welfare through inappropriate disclosure of information. In particular, counsel for the child should be wary about disclosing information obtained from the child to parents or various professionals if this might negatively affect the child's relationship with those individuals.

- Contacting Parents and Collaterals: Counsel appointed to represent a child should generally meet with the child's parents, and will often find it valuable to meet or have contact with other family members, foster parents or with other professionals, such as teachers. Counsel for a child should only make contact with parents or other parties to the litigation with the permission of their counsel. If counsel for the child establishes that the child is competent, thereafter counsel should contact the parents and others only with the consent of the child. While efforts should be made to protect the privacy of those who meet with child's counsel, they should not be assured of confidentiality of communications with the child's lawyer.

- Investigation of Placement and Resources: Counsel for a child has a responsibility to investigate possible placements, resources and child-care arrangements, including such arrangements as providing for ongoing contact with siblings or relatives. In some cases, it may be desirable for counsel for the child to retain a social worker or other person to assist with this investigation.

- Assessing Capacity and Deciding Role: A major issue for counsel for a child will be assessing whether the child has legal capacity to instruct counsel and is willing to provide instructions. While in some cases this can be easily determined, in other cases this may take several interviews or may even require retaining the services of a psychologist or other expert. It is possible that at one point in time a child will not have capacity (or willingness) to instruct counsel, but that this will change over time, or that the child will only have capacity and willingness to provide instructions about some matters, but not others, which will have to be resolved by counsel. If counsel concludes that the child lacks capacity, then counsel must make a decision about what role to adopt in the proceedings.

- Making Known Counsel's Role: Once counsel has assessed a child's capacity and determined the role that will be played in the proceedings, counsel for the child should ensure that the child, the parents and other parties are informed of the role that counsel will play in the proceedings. The court should also be informed of the role that counsel intends to play, at the latest at the start of any hearing, though in some cases counsel may decide that a best interest guardian role is to be adopted and not finalize a position until 
all of the evidence is before the court. Counsel for a child should only assure a child of confidentiality after counsel has decided to play an advocate's role. Even if a child lacks capacity and counsel decides that solicitor-client privilege will not apply to communications from the child, counsel should exercise caution in disclosing sensitive information received from the child, especially if it may be learned by the parents. Parents and other parties should be made aware of the effect that counsel's role will have in regard to such matters as confidentiality of communication from the child.

- Facilitation of Settlement: It will normally be in the interests of a child, especially in litigation between separated parents, for a dispute to be resolved on the basis of a settlement rather than after a trial, and counsel for a child may have an important role in facilitating settlement. In proceedings between parents, child's counsel should appreciate that these are the individuals who have ultimate responsibility for the child's care, and counsel should be respectful of their role and legal rights in any settlement negotiations. However, in a child protection proceeding, where the state is a party, a child's counsel may take a different position than the other parties based either on the child's instructions or counsel's assessment of the child's best interests, even where the other parties all agree upon a position.

- Keeping the Child's Interests Before the Court and Other Parties: Counsel for the child has a responsibility to ensure that the court and the adult parties take account of the child's interests, for example regarding extracurricular activities or visits with friends. In some cases, the making of satisfactory interim arrangements may be very important to a child and should be a focus of counsel's efforts.

- Ensuring that Child's Views and Preferences Are Before the Courr: Whatever role is adopted, counsel for a child should ensure that a child's views are determined and placed in evidence before the court. Unless all parties consent to child's counsel providing this material by way of submissions, ${ }^{\text {,t }}$ the child's views, preferences and observations should normally be introduced in court through admissible evidence. ${ }^{65} \mathrm{~A}$ lawyer for the child can, and should, make submissions to the court about the "position" of counsel in regard to the

There are cases in which the courts have, with the consent of the other partics, made determinations about the "wishes of a child" hased on the submissions of counsel for the child: e.g. Catholic Children 's Aid Society of Toronto v. M.R. (2003), 126 A.C.W.S. (3d) 966 (Ont. Cl. J.).

The Ontario Court of Appeal in Strobridge v. Strobridge (1994), 18 O.R. (3d) 753 at 764 held that a lawyer appointed for a child should not give "evidence" about the wishes of a child, with Osborne J.A. stating:

Counsel retained by the Oflicial Guardian is entitled to file or call evidence and make submissions on all of the evidence. In my view, counsel is not entitled so express his or her personal opinion on any issue, including the children's best interests. Nor is counsel entitled to become a witnuss and advise the court what the children's aceess-related preferences are. If those preferences should be before the court, resort must be had to the appropriate evidentiary means....The Olficial Guardian, througli counsel, will see that evidence going to the issue of the children's best interests is before the courts.

I do not view the children's perceptions of their needs and best interests, including their views as to the parent with whom they would like to live, as matters which should logically be considered to be outside the perimeters of the children's best interests.

While this decision affects how counsel for children in Ontario present their case, as discussed above, the policy of the Office of the Children's Lawyer now guides counsel in that province. 
litigation, including indicating what the child's instructions (or wishes) are, if counsel has determined that the child has capacity to instruct counsel. ${ }^{66}$ However, absent the consent of the parties about the admission of statements from the child through counsel, it is preferable for evidence about the child's views, observations and preferences to be put before the court by a social worker or other witness who has interviewed the child. That witness can testify and be cross-examined about exactly what was said by the child, describe the circumstances in which this information was communicated, explain its context and, if qualified as an expert, offer an opinion about the relationship of the child's views to the child's interests. This will generally require testimony or a report from a social worker or other person who has interviewed the child.

- The Child Communicating with the Court: Unless the child has the capacity to instruct counsel and expresses a clear desire to testify, counsel for a child should take steps to ensure that a child is not a witness, as this experience is likely to be very stressful to the child and may not give the court an accurate impression of the child. If the child is competent and wishes to communicate directly with the court, counsel for the child should facilitate this communication, perhaps by having the child write a letter to the court or making a videotaped statement. If the child is to be a witness, ${ }^{67}$ counsel for the child should advocate for measures to reduce the emotional trauma of testifying, for example by having the parents removed from the court room or through use of closed circuit television, and by ensuring that any cross-examination is carefully controlled ${ }^{6 \mathrm{k}}$ From the child's perspective, an interview in chambers with counsel for the child present is preferable to testifying in court.

- Ensuring Evidence Is Before the Court: Unless given clear contrary directions by a child competent to provide instructions, counsel for a child has the responsibility to ensure that all relevant evidence about the child's best interests is before the court. Normally, the adult and agency parties should take the lead in presenting evidence in court, but counsel

th. In Albesla (Director of Child Welfure) v. M.R., [2003] A.J. No. 1728 (Q.B.) (QL) it was held that counsel appointed to represent a 12-year-old boy in a permanent guardianship application could tell the court that the boy did not wish to see his father. Justice Hughes observed (at para. 14) that counsel for the child "understands the importance of taking instructions from clients.... [the trial judge| was able to in fact rely on that submission of counsel, and that no evidence [of the boy's wishes] was required." See Director of Child Welfore (Alla.) v. C.T.B. (1993), 139 A.R. 250 (Q.13.) for a discussion of the concerns about calling a child as a witness in a child protection case. Justice Dixon noted that the $C h i l d$ Welfare Act, S.A. 1984. c. C.8.I, s. 21(1)(c) provides that children under 12 are not entitled to notice of the proceeding, and remarked (at para. 4):

[A] child under the age of 12 has probably not reached a stage of development or maturity that would enable him or her to assume an active role in the proceedings. Also ... children ought to be spared the difficulty of appreciating the nature and extent of the issues before the court and of being placed in the potentially traumatic position of having to give testimony adverse to cither a former or present carcgiver. I accept these considerations as being valid.

See also Lee J. in M.E.S. v. D.A.S. (2001). 304 A.R. 1 12, 2001 ABQB 101 5, expressing concerns aboul having a parent call the child as a witness.

In Quebec, where it is nol uncommon for children who wish to communicate directly with the court to testify in family law cases, the nomal court process is generally modified for these witnesses. Questions that counsel for the parents wish to pose are sereened by the court, and are asked by counsel lor the child or the judge. It is not uncommon for the parents to be asked to leave the courtroom while the child testifies. Sec Sylvic Schrim \& Pascale Vallant. La Représentation des Enfants en Matière Familiale: Leurs Druits, Lewr Avenir (Cowansville, Que.: Yvon Blais, 2004), cc. VIl and X. 
for the child may have a role in presenting evidence and cross-examination of witnesses in order to ensure that the court has as complete information as reasonably possible.

- Keeping in Contact with the Child: Counsel for the child should maintain contact with the child as the case progresses. Provided the child has some capacity to appreciate the nature of the proceedings, counsel should keep the child informed of developments and decisions and ascertain whether the child's views and preferences have changed as the case progresses.

- Ending the Relationship: Counsel should prepare a child for the end of the relationship with counsel prior to its termination at the completion of the proceedings, and should tell the child when and how to contact counsel in the future.

- Withdrawing From a Case: Child representation is challenging work and some child clients, especially adolescents, can be frustrating to deal with, unreliable, mistrusting, defiant or uncommunicative.

If the child has capacity to instruct counsel and counsel has assumed an advocate role, the child has the right to terminate the representation, in which case counsel should use reasonable efforts to assist the child in obtaining new counsel. However, if counsel for the child has been appointed by the court and the proceedings are continuing, the issue of dismissal of counsel by the child should be brought before the court. In some cases it may be appropriate for the court to instruct that counsel is to remain the child's lawyer, albeit assuming the role of friend of the court or best interests guardian.

During the course of representing a child, counsel may decide that it is appropriate to withdraw, even if the child is not legally competent to instruct counsel. Withdrawal from representation of a child should not be undertaken lightly and should be handled with particular sensitivity as the child may have already experienced disruption of relationships with trusted adults. Counsel should only voluntarily withdraw if other competent counsel can be found to represent the child and resolution of the case will not be unduly delayed. If counsel for the child has been appointed by the court and the proceedings are continuing, judicial approval will be required as well.

- Future Proceedings: Family law and child welfare cases often are not truly concluded by a court order or settlement, but may be subject to variation or review proceedings if circumstances change. When the proceedings conclude, counsel should give the child a business card and inform that child that counsel may be contacted in the future. If there is a variation or review, counsel may need to be again appointed by the court to represent the child, but it is usually preferable to have counsel who knows the child reappointed.

\section{CONClusion: LAw SOCIETY AND GovernMeNT ReSPONSIBILITIES}

As a result of changes in government policy and legislation, as well as changes in judicial attitude and the Charter," in recent years there has been an increase in the number of cases 
in which counsel have been appointed to represent children in Alberta. The Government of Alberta is spending significant sums on child representation, and there is some restructuring of child representation underway in the province, with responsibility for lawyers appointed to represent children in child welfare proceedings being transferred to the Office of the Child and Youth Advocate. ${ }^{70}$ There is not, however, an organized child representation program in the province, and representation in cases involving separated parents is not within the mandate of any government department or agency. It is time for the Government of Alberta to meet its responsibilities to the children of the province by dealing in a coherent fashion with such issues as the recruitment, screening, education and monitoring of counsel who provide representation to children, as well as addressing critical issues related to financial resources and appropriate support services for the lawyers who do this type of work.

This article addresses important questions about the appropriate role for counsel appointed to represent children in family cases and standards for their handling of these most challenging cases. It provides guidance for counsel, in the absence of direction from appropriate bodies. If the Alberta Government fails to address issues related to the role of counsel, the Law Society of Alberta should address issues of professional obligations and role of counsel for the child. The discussion in this article should be a useful starting point for those bodies.

Legal scholars and social scientists must also continue to engage in the study of these issues. There is a clear need for more research in Canada about such questions as how lawyers for children actually carry out their professional responsibilities, how children perceive the justice system and their lawyers and the effect of child representation on the lives of children and their families. 